\title{
NOSQL TECHNOLOGY IN ANDROID BASED MOBILE CHAT APPLICATION USING MONGODB
}

\author{
Yovita Tunardi; Rita Layona \\ Computer Science Department, School of Computer Science, Binus University \\ Jl. K.H. Syahdan No. 9, Palmerah, Jakarta Barat 11480 \\ ytunardi@binus.edu,rlayona@binus.edu
}

\begin{abstract}
Along with the development of data storage technology which previously using relational concept began to change to the non-relational concept or sometimes referred to as the term NoSQL technology. Data storage in NoSQL is no longer based on the relations between tables but using another methods, one of them is document-oriented. This method was applied specifically in MongoDB. This concept brings new hope because of their superiority that can handle very large data with promising performance and is perfect for agile system development. The purpose of this research was to measure the performance NoSQL, especially MongoDB with implemented it in a Android based mobile chat application. This research uses three methods, analysis method including literature study, analysis of similar application, questionnaires, design method using Agile Sofware Development, and evaluation method including eight golden rules, analysis of similar application, questionnaires, and interview. The results of this research is a mobile chat application that uses MongoDB as the data storage technology. Through this research can be drawn the conclusion that NoSQL technology implementation, MongoDB, give special advantages like lighter data storage and faster data access.
\end{abstract}

Keywords: NoSQL, Android, Chat, MongoDB

\begin{abstract}
ABSTRAK
Seiring dengan berkembangnya teknologi penyimpanan data yang sebelumnya bersifat relational mulai berubah ke arah non-relational atau yang sering dikenal dengan istilah teknologi NoSQL. Penyimpanan data pada NoSQL tidak lagi didasarkan pada relasi antar tabel tapi menggunakan metode lain yang salah satunya adalah document-oriented. Metode tersebut diaplikasikan secara khusus pada MongoDB. Konsep tersebut membawa harapan baru karena keunggulannya yang dapat menangani data yang sangat besar dengan performa yang menjanjikan dan sangat cocok untuk pengembangan sistem yang agile. Tujuan dari penelitian ini adalah mengukur performa dari NoSQL khususnya MongoDB dengan cara mengimplementasikannya ke dalam mobile chat application yang berbasis Android. Metode penelitian yang digunakan terdiri dari tiga yaitu metode analisis yang meliputi studi literatur, analisis aplikasi sejenis, dan kuesione, metode perancangan yang menggunakan metode Agile Sofware Development, dan metode evaluasi yang meliputi evaluasi berdasarkan delapan aturan emas, aplikasi sejenis, kuesioner, dan wawancara. Hasil dari penelitian ini adalah sebuah mobile chat application yang menggunakan MongoDB sebagai teknologi penyimpanan datanya. Melalui penelitian ini dapat ditarik simpulan bahwa penerapan teknologi NoSQL khususnya MongoDB memberikan keunggulan khusus dalam hal penyimpanan data yang lebih ringan dan pengaksesan data yang lebih cepat.
\end{abstract}

Kata kunci: NoSQL, Android, Chat, MongoDB 


\section{PENDAHULUAN}

Teknologi penyimpanan data selalu berkembang sesuai dengan zaman dan kebutuhan. Mulai dari penyimpanan dengan hierarchical database yang berbentuk seperti sebuah struktur pohon yang saling terkait, network database yang terdiri dari record yang saling berhubungan dengan menggunakan pointer, sampai relational database yang sudah cukup modern di mana data sudah tertata dengan rapi dalam bentuk tabel yang saling berhubungan satu sama lain. Teknologi relational database sangat sering digunakan dalam pengembangan aplikasi karena keunggulannya yang terstruktur dan memungkinkan dimanipulasi dengan mudah. Namun, seiring dengan perkembangan zaman, teknologi tersebut masih dirasa kurang karena data yang semakin banyak dan data harus dapat diakses dengan cepat sehingga kemudian muncul teknologi baru yaitu non-relational database atau yang sering dikenal dengan istilah database NoSQL.

Penyimpanan data pada NoSQL tidak lagi didasarkan pada relasi antar tabel tapi menggunakan metode lain yaitu key-value, big table, document-oriented, dan graph. Salah satu jenis dari teknologi NoSQL adalah MongoDB yang berbasis pada metode document-oriented. NoSQL dan MongoDB secara khusus membawa harapan baru bagi masyarakat karena keunggulannya yang dapat menangani data yang sangat besar dengan performa yang menjanjikan dan sangat cocok untuk pengembangan sistem yang agile (Tiwari, 2011). Menurut Idrees (2012), ada beberapa fitur utama dari MongoDB yang membuatnya menjadi pilihan yang baik, yaitu penanganan data yang sangat besar, mendukung operasi asynchronousinsert, dan pengolahan data dengan MapReduce sehingga MongoDB dijadikan pilihan database yang unggul dalam segi kecepatan dan besar penyimpanan.

Oleh karena itu, pada penelitian ini akan diteliti bagaimana NoSQL, khususnya MongoDB, dapat diimplementasikan dalam bentuk aplikasi yang dapat menjawab kebutuhan dari masyarakat tersebut. Aplikasi yang akan dikembangkan sebagai bahan penelitian adalah sebuah mobile chat applicationyang berbasis sistem operasi Android. Aplikasi jenis ini dipilih karena merupakan salah satu aplikasi yang berdasarkan memori penyimpanan yang dimiliki relatif kecil sehingga hanya dapat menyimpan data yang besarnya terbatas dan untuk akses data dibutuhkan cepat. Sistem operasi Android dipilih dalam penelitian ini melihat dari data prediksi market share dari tahun 2013 sampai tahun 2017, Android menempati posisi teratas dengan market share lebih dari 50\%.

Tabel 1 Data dan Forecast Market Share Sistem Operasi Smartphone, 2013-2017

(Sumber: www.idc.com, 2013)

\begin{tabular}{|l|r|r|}
\hline Smartphone OS & 2013 Market Share & 2017 Market Share \\
\hline \hline Android & $75.3 \%$ & $68.3 \%$ \\
\hline \hline iOS & $16.9 \%$ & $17.9 \%$ \\
\hline \hline Windows Phone & $3.9 \%$ & $10.2 \%$ \\
\hline \hline BlackBerry OS & $2.7 \%$ & $1.7 \%$ \\
\hline \hline Others & $1.2 \%$ & $1.9 \%$ \\
\hline \hline Totals & $\mathbf{1 0 0 . 0} \%$ & $\mathbf{1 0 0 . 0} \%$ \\
\hline
\end{tabular}


Hasil penelitian ini diharapkan dapat memberi hasil gambaran implementasi teknologi NoSQL, secara khusus MongoDB, untuk mobile chat application dilihat bukan hanya dari sisi fitur yang disediakan tapi juga dari segi besar penyimpanan data yang dibutuhkan lebih sedikit dan kecepatan akses yang dalam hal ini adalah kecepatan pengiriman dan penerimaan pesan menjadi lebih cepat dibandingkan aplikasi lainnya yang tidak menggunakan NoSQL, khususnya MongoDB.

\section{METODE}

Metodologi penelitian yang digunakan terdiri dari tiga metode utama yaitu metode analisis, metode perancangan, dan metode evaluasi.

\section{Metode Analisis}

Metode analisis yang dilakukan dalam penelitian ini terdiri dari studi literatur, analisis aplikasi sejenis, dan kuesioner. (1) Studi literatur - Studi literatur dilakukan sebagai tahap awal sebelum memulai penelitian dengan mengumpulkan teori-teori yang sudah dikemukakan oleh para pakar dalam bentuk buku dan artikel. Selain itu dilakukan juga studi literatur akan penelitian yang sudah pernah dilakukan sebelumnya untuk mendapatkan data metode yang sudah pernah digunakan sebelumnya dan hasil dari penelitian tersebut, yang didapatkan dari paper dan jurnal nasional maupun internasional. Hasil dari studi literatur tersebut dianalisis dan dijadikan acuan awal dalam penelitian ini. (2) Analisis aplikasi sejenis - Analisis aplikasi sejenis dilakukan untuk mendapatkan informasi pendukung dari aplikasi sejenis lainnya sebagai perbandingan. Perbandingan dilakukan berdasarkan besar penyimpanan data dan kecepatan akses. Hal tersebut juga tidak lepas dari fitur-fitur pendukung pada aplikasi yang tentu akan sangat mempengaruhi dua hal tersebut.Aplikasi sejenis yang akan dianalisis adalah Blackberry Messenger, WhatsApp Messenger, dan Line Messenger. (3) Kuesioner - Kuesioner dilakukan dengan cara membagikan kuesioner kebutuhan user untuk membantu dalam proses implementasi MongoDB dalam bentuk mobile chat application yang sesuai dengan kebutuhan user bukan hanya dalam hal fitur tetapi juga dalam penyimpanan data dan kecepatan akses. Analisis ini dilaksanakan dengan menyebarkan kuesioner yang berisi 10 pertanyaan ke pelajar, mahasiswa, dan karyawan. Adapun beberapa hal yang ditanyakan dalam kuesioner tersebut adalah umur, jenis kelamin, profesi, jenis smartphoneyang dimiliki, cara berkomunikasi, masalah-masalah yang selama ini dirasakan dalam kegiatan chatting khususnya dalam penyimpanan data dan kecepatan akses, dan harapan akan fitur lainnya.

\section{Metode Perancangan}

Metode perancangan yang digunakan adalah salah satu metode Agile Sofware Development yaitu Extreme Programming. Mobile chat application dirancang dan dikembangkan melalui empat tahap sesuai dengan metode agile yaitu: (1) Tahap Perancangan (Planning). (2) Tahap Desain (Design). (3) Tahap Pengembangan (Coding). (4) Tahap Pengujian (Testing). Metode ini dipilih karena berdasarkan teori dan penelitian yang sebelumnya dilakukan, diketahui bahwa NoSQL khususnya MongoDB sangat cocok dan unggul jika diterapkan untuk pengembangan sistem yang agile. Metode agile ini sendri juga sangat cocok dalam pengembangan mobile chat application karena memungkinkan proses pengembangan aplikasi untuk kembali ke proses sebelumnya (refactoring) dan juga menjamin real-time problem solving dan real-time quality assurance (Pressman, 2010). 


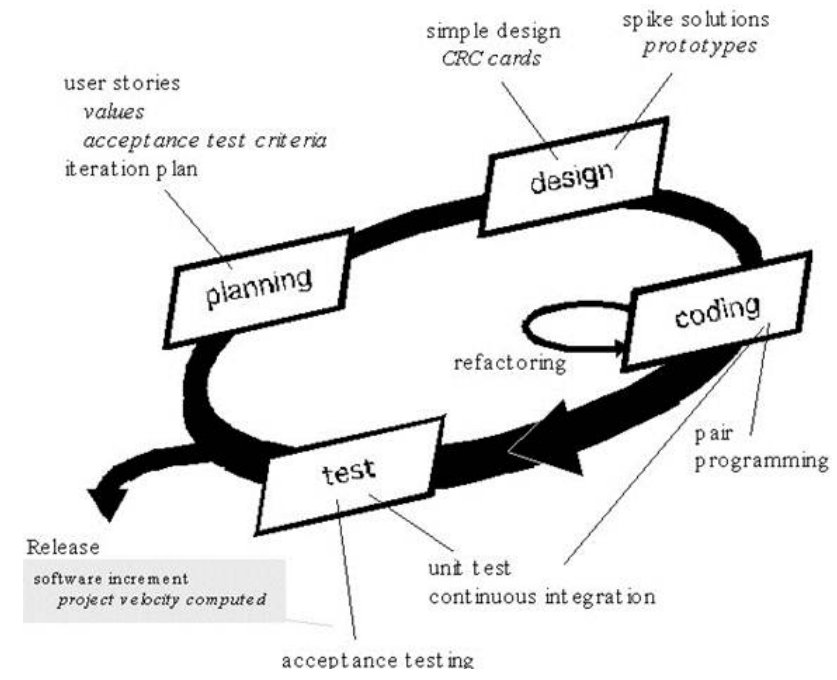

Gambar 1Metode Pendekatan Extreme Programming

(Sumber: Software Engineering: A Practitioners Approach, Pressman, 2010)

\section{Metode Evaluasi}

Metode evaluasi yang dilakukan dalam penelitian ini terdiri dari evaluasi berdasarkan delapan aturan emas, aplikasi sejenis, kuesioner, wawancara, lima faktor manusia terukur, dan sepuluh prinsip perancangan mobile application. (1) Delapan aturan emas - Aplikasi dievaluasi berdasarkan delapan aturan emas, yaitu konsistensi, fungsi yang universal, umpan balik informatif, dialog untuk penutupan, pencegahan kesalahan sederhana, pengembalian ke aksi sebelumnya, pengendalian internal, dan mengurangi beban ingatan jangka pendek. (2) Aplikasi sejenis - Evaluasi terhadap aplikasi sejenis dilakukan berdasarkan fitur, besar penyimpanan data, dan kecepatan akses dari Blackberry Messenger, WhatsApp Messenger, dan Line Messenger dibandingkan dengan aplikasi yang dikembangkan. (3) Kuesioner - Kuesioner dilakukan dengan cara membagikan kuesioner evaluasi untuk mengevaluasi implementasi MongoDB dalam bentuk mobile chat application, bukan hanya dalam hal fitur tetapi juga dalam penyimpanan data dan kecepatan akses.Analisis ini dilaksanakan dengan menyebarkan kuesioner yang berisi 12 pertanyaan ke pelajar, mahasiswa, dan karyawan. Adapun beberapa hal yang ditanyakan dalam kuesioner tersebut adalah mengenai kelengkapan fitur aplikasi dan kecepatan pengiriman pesan. (4) Wawancara - Wawancara dilakukan kepada para pakar dalam bidang Information Technology (IT) dan dijadikan sebagai salah satu metode evaluasi aplikasi yang dikembangkan khususnya mengacu pada database yang digunakan yaitu MongoDB. Wawancara dilakukan pada 10 responden yang merupakan pakar IT yang meliputi para pekerja IT dan staff pengajar bidang IT. Melalui wawancara diperoleh kelebihan dan kekurangan dari aplikasi, fungsionalitasnya, performa seperti kecepatan dan besar penyimpanannya, desain, dan saran untuk penelitian selanjutnya.

\section{Tinjauan Pustaka}

\section{Android}

Menurut Darcey dan Conder (2012), Android merupakan sebuah mobile platform pertama yang lengkap, opensource, dan gratis yang dikembangkan dengan menggunakan Software Development Kit yang comprehensive untuk mengembangkan aplikasi yang powerful dan kaya akan fitur. Menurut Gargenta (2011), Android merupakan sebuah comprehensive open-source platform yang didesain untuk perangkat mobile. Android dimiliki oleh Open Handset Alliance dan dipelopori 
oleh Google. Menurut Meier (2011), Android adalah gabungan dari tiga komponen, komponen tersebut yaitu: sebuah open-sourceoperating system yang digunakan untuk perangkat mobile, sebuah open-source platform yang digunakan untuk membuat aplikasi mobile dan sebuah perangkat, terutama mobilephone, yang menjalankan Android operating system dan aplikasi yang dibuat di sistem operasi itu.

\section{Keunggulan Android}

Menurut Meier (2011), terdapat beberapa keunggulan dan fitur-fitur yang dimiliki oleh android Android, yaitu: (1) Aplikasi Google Maps - Google Maps yang disediakan untuk mobile sangat populer dan Android menawarkan aplikasi Google Maps yang dapat digunakan untuk aplikasi lain. (2) Background services and applications - Background services memungkinkan pengembang aplikasi untuk membuat sebuah aplikasi yang menggunakan event, di mana aplikasi berjalan tanpa terlihat bahwa aplikasi tersebut sedang berjalan ketika aplikasi lain sedang dijalankan. (3) Sharing data dan InterProcess Communication (IPC) - Android memungkinkan pertukaran pesan, melakukan pengolahan, dan berbagi data dengan menggunakan Content Provider. (4) Semua aplikasi yang dibuat sama - Android tidak membedakan aplikasi yang asli dengan aplikasi yang dikembangkan oleh pihak ketiga/third parties.

\section{Jenis Aplikasi Android}

Menurut Meier (2011), sebagian besar aplikasi yang dibuat menggunakan Android akan termasuk dalam salah satu kategori berikut: (1) Foreground - Foreground merupakan sebuah aplikasi yang berguna ketika ada pada foreground dan tidak efektif ketika tidak terlihat. Contohnya adalah games dan mapmashups. (2) Background - Background merupakan sebuah aplikasi dengan interaksi yang terbatas, Contohnya aplikasi call screening dan Short Message Service (SMS) auto-responder. (3) Intermittent - Intermittent merupakan sebuah aplikasi yang dapat jalan di foreground dan background, aplikasi ini biasanya dibentuk dan kemudian dijalankan secara tersembunyi (background) dan memberitahu pengguna di saat yang tepat. Contohnya adalah media player. (4) Widget - Widget adalah aplikasi yang dibuat hanya untuk ditampilkan sebagai widget pada screenhome.

Menurut Helal et al. (2012), terdapat empat jenis komponen yang ada dalam aplikasi Android, Komponen tersebut adalah sebagai berikut: (1) Activity - Sebuah activity mewakili user interface aplikasi yang didefinisikan pada activity class. Contoh: pada music player application memiliki satu activity untuk memutar lagu dan satu activity lainnya untuk memilih album atau audio file. (2) Service - Service akan berjalan secara tersembunyi dantidak secara langsung berinteraksi dengan user. Komponen ini berjalan di backgrounddan tidak memiliki user interface. (3) Content Provider Content provider adalah tempat untuk menyimpan dan membagikan data dengan aplikasi lain. (4) Broadcast Receiver - Broadcast receiver bertugas untuk merespon pengumuman sistem siaran.

Gambar berikut merupakan arsitektur Android yang terdiri dari komponen-komponen utama dari sistem operasi Android yang dibagi menjadi beberapa bagian (layer) 


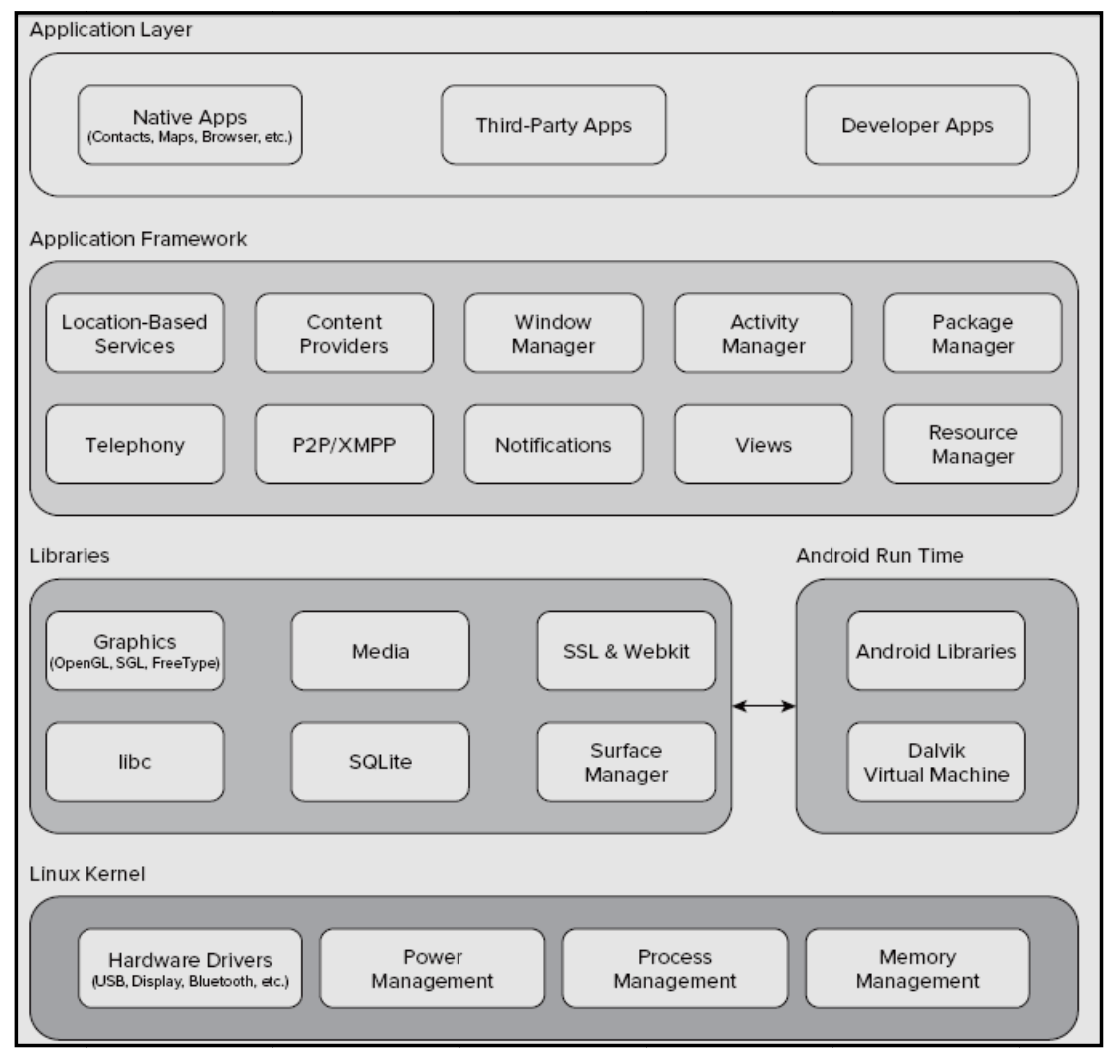

Gambar 2 Arsitektur Android

(Sumber : Professional Android 2 Application Development, Meier, 2011)

Komponen-komponen utama dari arsitektur sistem operasi Android adalah: (1) Linux Kernel - Linux Kernel merupakan komponen paling bawah dari arsiktektur Android. Linux Kernel menangani service inti seperti perangkat keras, proses dan memory management, sekuritas, jaringan, dan power management. (2) Libraries - Libraries berjalan di atas dari komponen Kernel. Android memasukkan berbagai library inti dari $\mathrm{C} / \mathrm{C}++$ termasuk libc dan SSL, serta Medialibrary untuk memutar kembali media audio dan video, Surface manager untuk menyediakan pengaturan tampilan, Graphics libraries yang mencakup SGL dan OpenGL untuk 2D dan 3D graphics, SQLite untuk dukungan pada database aslinya serta SSL dan WebKit untuk integrasi web browser dan sekuritas internet. (3) Android run time - Android run time merupakan engine yang berfungsi untuk menjalankan aplikasi Android dan bersama dengan libraries. (4) ApplicationFramework - Application Framework menyediakan class yang digunakan untuk membuat aplikasi Android. (5) Application layer - Semua aplikasi dibuat di application layer dengan menggunakan library API. Application layer berjalan di dalam Android run time dengan menggunakan class-class dan service yang dibuat dari application framework.

\section{MongoDB}

MongoDB merupaan salah satu jenis database NoSQL, yang merupakan sebuah konsep penyimpana non-relational data. Ada empat metode berbeda yang dipakai oleh database jenis ini untuk menyimpan data, yaitu key-value, big table, document-oriented, dan graph. Metode yang dipakai oleh MongoDB adalah document-oriented yang menyimpan dokumen seperti JavaScript Object Notation (JSON) (Tiwari, 2011). 


\section{Fitur dan Kelebihan MongoDB}

Menurut Idrees (2012), ada beberapa fitur utama dari MongoDB yang membuatnya menjadi pilihan yang baik, yaitu sebagai berikut: (1) Penanganan data yang sangat besar - Sistem database relasional mulai menjadi terlalu mahal dalam hal sumber daya sistem. Data yang sangat besar memerlukan pengolahan yang lebih dan akan menghabiskan banyak waktu dan juga tempat. MongoDB dapat menjadi alternatif yang lebih baik. (2) Mendukung operasi asynchronousinsert Cara kerja dari MongoDB dalam proses insert adalah dengan memasukkan dokumen dan melanjutkan ke tugas berikutnya tanpa menunggu respon dari server. Hal tersebut membebaskan aplikasi untuk melakukan tugasnya tanpa terjebak pada satu operasi database yang lama dan dapat meningkatkan respons pengguna. (3) Pengolahan data dengan MapReduce - MapReduce adalah sebuah pendekatan untuk pengolahan data yang memiliki dua manfaat dibanding solusi tradisional lainnya, yaitu performa yang lebih baik dan penulisan realcode untuk mengolah data. MapReduce juga membuat operasi aggregate dan query data menjadi lebih mudah.

Selain fitur utama tersebut, menurut Jayathiloha et al. (2012) terdapat beberapa alasan MongoDB dijadikan pilihan dibanding produk database NoSQL lainnya, yaitu: (1) Schema free MongoDB tidak memiliki schema sehingga biasa disebut schema-free database. Hal tersebut memungkinkan penyimpanan data dengan struktur yang berbeda dalam satu collection. (2) Agile development - MongoDB merupakan pilihan yang sangat tepat untuk pengembangan software secara Agile. MongoDB dapat mengatasi banyaknya perubahan dalam agile development karena sifatnya yang schema-free sehingga schema dapat berubah sesuai dengan perubahan persyaratan. (3) Flexible document - Penyimpanan data MongoDB berbeda dari database lainnya yaitu dalam bentuk dokumen yang dapat berupa arraydan hash. Dokumen MongoDB disimpan sebagai objek JSON yang biasa disebut binary JSON (BSON). (4) Cloud ready - MongoDBsiapuntuk dijalankan pada commodityhardware, virtualizedenvironments, dan cloud. MongoDB dapat berjalan dengan baik pada hardware jenis apapun. (5) High performance - MongoDB tidak menggunakan join seperti database umumnya karena MongoDB dapat berisi gabungan field seperti array dan hash. MongoDB juga mendukung indexing yang akan meningkatkanperforma dari query. (6) Horizontally scalable Berbeda dengan RDMS yang melakukan vertical scaling, MongoDB termasuk horizontally scalable yang berarti skalabilitas data dimungkinkan dengan menambahkan beberapa server dan tidak perlu melakukan upgrade server.

\section{Konsep Dasar MongoDB}

Seguin (2012) mengatakan bahwa ada enam konsep dasar yang perlu diketahui mengenai MongoDB, yaitu sebagai berikut: (1) MongoDB memiliki konsep yang sama dengan database pada umumnya seperti MySQL dan Windows SQL Server. MongoDBdapat memiliki nol atau lebih database. (2) Sebuah database dapat memiliki nol atau lebih collection yang dapat disetarakan dengan table pada database umumnya. (3) Sebuah collection terdiri dari nol atau lebih dokumen yang dapat disetarakan dengan baris pada database umumnya. (4) Sebuah dokumen terdiri dari satu atau lebih fields yang dapat disetarakan dengan kolom pada database umumnya. (5) MongoDB memiliki indeks yang memiliki fungsi sama seperti indeks pada database umumnya. (6) Data dari MongoDB akan dikembalikan dalam bentuk kursor.

MongoDB bersifat client-server. Sisi server sebagai tempat proses data dan untuk penulisan instruksi pada sisi client. Pengaksesan database dilakukan dengan instruksi use DATABASE_NAME seperti use learn. Instruksi tersebut akan mengakses database learn yang sudah ada atau membuat baru jika belum ada ketika proses insert pertama. Instruksi yang akan dieksekusi pada database dituliskan dengan menggunakan objek $\mathrm{db}$ seperti $\mathrm{db} . h e l p()$ atau db.stats(). Instruksi yang akan dieksekusi pada collection dituliskan dengan menggunakan objek db.COLLECTION_NAME seperti db.unicorns.help() atau db.unicorns.count(). 


\section{Select Data}

Menurut Seguin (2012), Select Data menampilkan data pada database MongoDB dapat dilakukan dengan menggunakan instruksi find, misalnya db.unicorns.find(). Instruksi find juga dapat memiliki parameter tambahan untuk pemberian syarat-syarat khusus dan pemilihan field yang ditampilkan.

\section{Insert Data}

Menurut Seguin (2012), proses insert data pada MongoDB dapat dilakukan dengan menggunakan instruksi insert atau save. Penggunaan insert akan langsung menambahkan data baru, sedangkan penggunaan save akan menyesuaikan dengan kondisi. Jika data yang ditambahkan belum ada, maka data akan ditambahkan, tetapi jika sudah ada maka data akan diubah. Sebagai contoh dapat dilihat seperti di bawah ini:

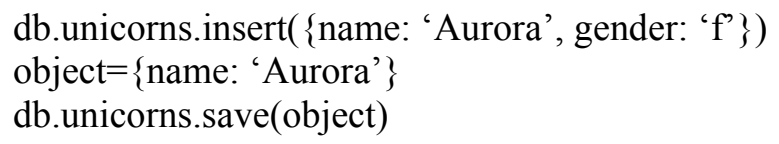

\section{Update Data}

Menurut Seguin (2012), proses update data pada MongoDB masih sering digunakan dengan tidak tepat karena memiliki konsep yang jauh berbeda dengan database pada umumnya seperti SQL. Instruksi yang digunakan adalah update dengan 2 parameter, syarat seleksi yang digunakan dan field mana yang akan diubah. Berikut adalah contoh penggunaannya:

db.unicorns.update(\{name: 'Roooooodles'\}, \{weight: 590\})

Instruksi tersebut akan menyebabkan replace data bukan update. Dokumen yang memiliki name Roooooodles akan diganti datanya dengan weight 590. Perubahan data untuk satu atau lebih field yang bukan bersifat replace dilakukan dengan menggunakan operator \$set. Berikut adalah cara penggunaanya:

db.unicorns.update(\{weight: 590$\}$, \{\$set: \{name: 'Roooooodles', dob: new Date $(1979,7$, 18, 18, 44), loves: ['apple'], gender: 'm', vampires: 99$\}\})$

\section{Delete Data}

Menurut Seguin (2012), menghapus data pada MongoDB dapat dilakukan dengan menggunakan instruksi remove. Seperti instruksi find dan update, remove juga dapat memiliki parameter sebagai syarat data mana yang akan dihapus. Berikut adalah cara penggunaannya:

db.unicorns.remove()

db.unicorns.remove( \{name: 'Roooooodles'\})

Berbeda lagi untuk penghapusan collection dari database. Hal tersebut dapat dilakukan dengan instruksi db.COLLECTION_NAME.drop() menjadi db.unicorns.drop().

\section{Data Modelling}

Menurut Seguin (2012), MongoDB tidak menggunakan JOIN seperti yang biasa dimiliki oleh database pada umumnya, tetapi dapat tetap dihubungkan secara manual seperti penggunaan foreign key di SQL. Langkah yang dapat dilakukan adalah dengan menyimpan _id dari satu dokumen dalam dokumen yang lain. Contohnya adalah sebagai berikut: 


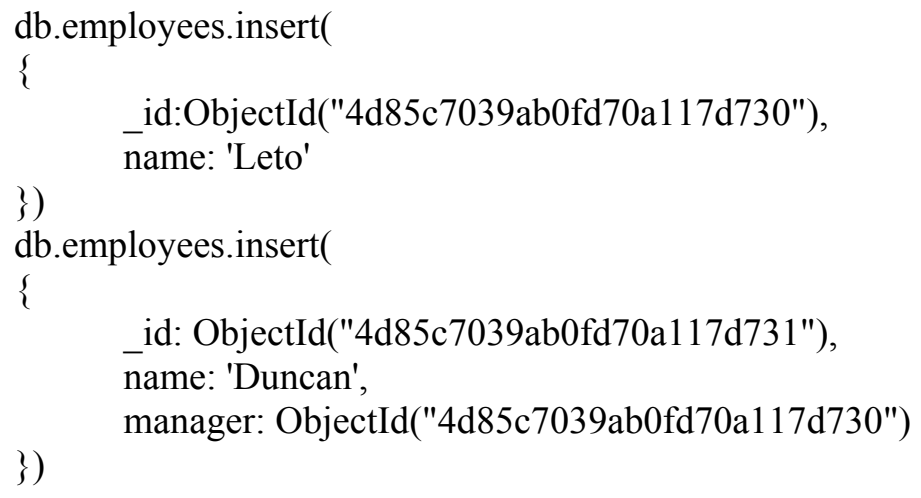

Pilihan lainnya adalah dengan menggunakan DBRef yang sudah disediakan oleh MongoDB. DBRef dapat digunakan untuk menghubungkan antara lebih dari satu dokumen dalam collection atau database yang berbeda. DBRef memiliki beberapa field sebagai berikut: (1) \$ref - Field \$ref akan berisi nama collection dimana dokumen yang akan dihubungkan berada. (2) \$id - Field \$id akan berisi nilai_id dari dokumen yang akan dihubungkan. (3) \$db - Field \$db bersifat optional dan akan berisi nama database dimana dokumen yang akan dihubungkan berada.

Dokumen DBRef akan terbentuk menjadi $\{$ \$ref : $<$ value $>$, \$id : $<$ value $>$, \$db $:<$ value $>\}$.

\section{Fitur Tambahan}

Menurut Seguin (2012), dalam MongoDB juga disediakan beberapa fitur tambahan lagi yang mendukung performa. Berikut akan dibahas beberapa hal yang akan sering digunakan pada database MongoDB:

\section{Indexes}

Indeks pada MongoDB berfungsi sama dengan indeks pada database relasional pada umumnya yang membantu performa query dan sorting data. Penambahan indeks dapat dilakukan dengan menggunakan instruksi ensureIndex. Penghapusan indeks dapat dilakukan dengan menggunakan instruksi dropIndex. Berikut adalah contoh penggunaannya:

$$
\begin{aligned}
& \text { db.unicorns.ensureIndex }(\{\text { name: } 1\}) \\
& \text { db.unicorns.dropIndex }(\{\text { name: } 1\}) ;
\end{aligned}
$$

Pembuatan unique index dapat dilakukan dengan menambahkan parameter kedua. Pengurutan indeks secara ascending ditandai dengan angka 1 dan secara descending ditandai dengan angka -1 seperti pada contoh sebagai berikut:

db.unicorns.ensureIndex(\{name: 1$\}$, \{unique: true $\})$;

db.unicorns.ensureIndex (\{name: 1, vampires: -1$\})$;

\section{Explain}

Pada MongoDB dapat dilakukan pengecekkan apakah suatu collection dan query menggunakan indeks. Instruksi yang digunakan adalah explain. Penggunaan instruksi db.unicorns.find().explain() akan menampilkan kursor yang digunakan adalah BasicCursor yang menandakan tidak adanya penggunaan indeks. Penggunaan instruksi db.unicorns.find(\{name: 'Pilot'\}).explain() akan menampilkan kursor yang digunakan adalah BtreeCursor adanya penggunaan indeks. 


\section{Backup dan Restore}

Backup dan restore pada MongoDB dapat dilakukan dengan menggunakan fileexecutable yang sudah disediakan oleh MongoDB. Backup dilakukan dengan menjalankan mongodump dengan diikuti pilihan database, collection, dan nama filebackup. Sedangkan untuk restore dengan menjalankan mongorestore dengan pilihan yang sama. Berikut adalah contoh penggunaannya:

$$
\begin{aligned}
& \text { mongodump --db learn -collection unicorns --out backup } \\
& \text { mongorestore --collection unicorns backup/learn/ } \\
& \text { unicorns.bson }
\end{aligned}
$$

Selain backup dan restore, MongoDB juga memungkinkan untuk proses import dan export. Fileexecutable yang digunakan adalah mongoimport dan mongoexport. Berikut adalah contoh penggunaannya:

$$
\begin{aligned}
& \text { mongoexport --db learn -collection unicorns } \\
& \text { mongoexport --db learn -collection unicorns --csv -fields name,weight,vampires }
\end{aligned}
$$

\section{HASIL DAN PEMBAHASAN}

Hasil dari penelitian ini didapat bahwa dengan menggunakan MongoDB untuk mobile chat application, aplikasi ini dapat menangani data yang besar dan memiliki pengaksesan data dan performa yang lebih baik dikarenakan mongoDB memiliki fitur operasi asynchronous insert dan pengolahan data menggunakan MapReduce. Berikut merupkan perbandingan memori penyimpanan aplikasi lain dengan aplikasi yang dibuat dengan mongoDb: (1) Memori penyimpanan WhatsApp Messenger adalah sebesar 11.46 MB. (2) Memori penyimpanan Line Messenger adalah sebesar 60.51 MB. (3) Memori penyimpanan Blackberry Messenger adalah sebesar 9.5 MB. (4) Memori penyimpanan Aplikasi dengan MongoDB adalah sebesar 6.53 MB.
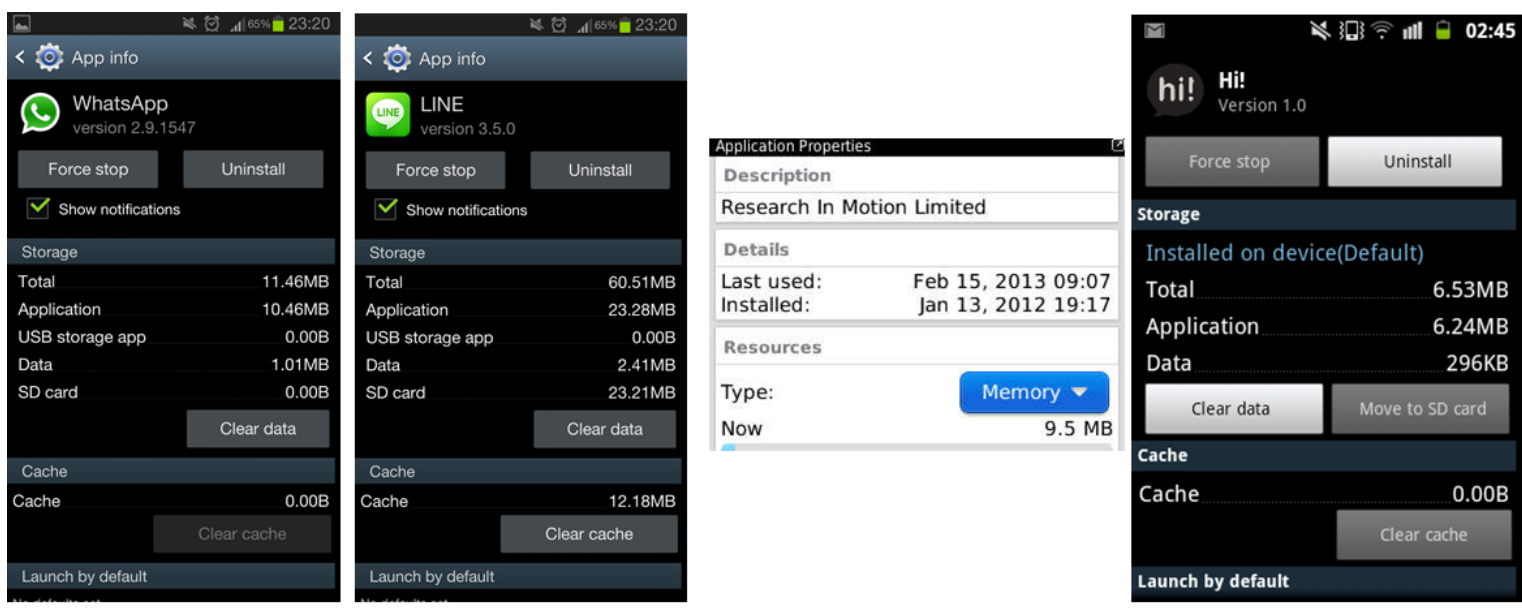

Gambar 3 Perbandingan Memori Penyimpanan 
Pada penelitian ini juga dilakukan enam jenis evaluasi untuk mobile chat application. Evaluasi tersebut meliputi evaluasi delapan aturan emas, evaluasi analisis aplikasi sejenis, evaluasi melalui kuesioner dan wawancara, evaluasi lima faktor manusia terukur, serta sepuluh prinsip perancangan mobile application berdasarkan Stark (2012).

\section{Evaluasi Terhadap Delapan Aturan Emas}

Mobile chat application sudah memenuhi delapan aturan emas, yaitu: berusaha untuk konsisten, menyediakan fungsi yang bersifat universal atau umum, memberikan umpan balik yang informatif, merancang dialog untuk menghasilkan penutupan, memberikan pencegahan terhadap kesalahan yang sederhana, memungkinkan pengembalian aksi yang sebelumnya, mendukung pengendalian internal dan mengurangi beban ingatan jangka pendek

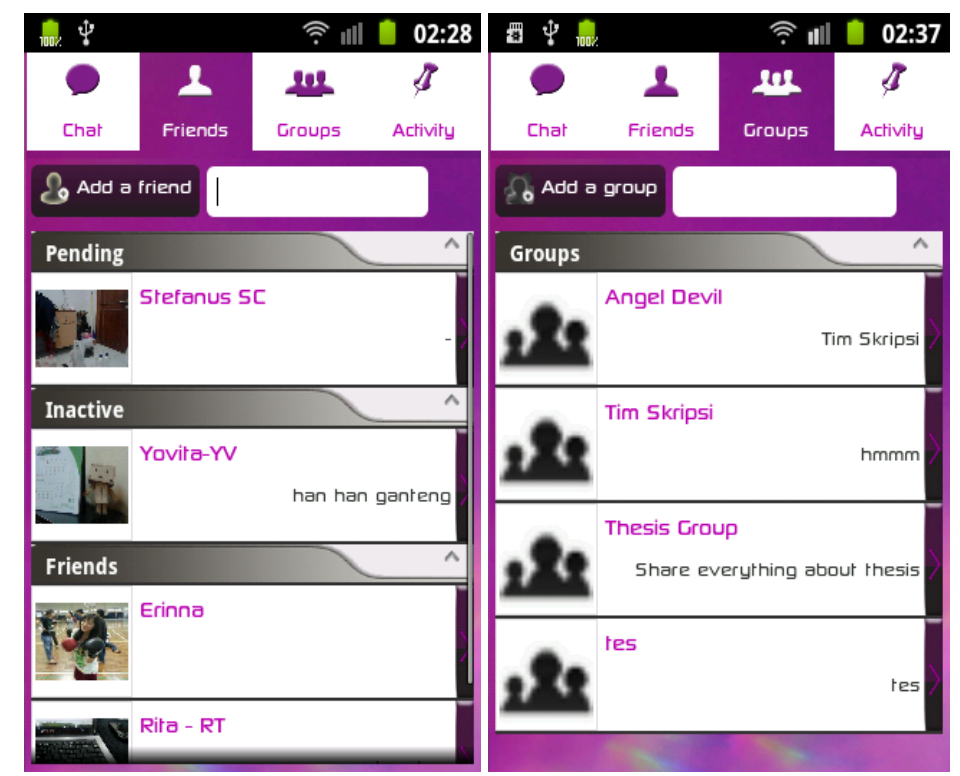

Gambar 4 Contoh Konsistensi Aplikasi

\section{Evaluasi Terhadap Aplikasi Sejenis}

Analisis dilakukan dengan membandingkan fitur yang dimiliki dengan aplikasi lainnya, seperti Blackberry Messenger, WhatsApp Messenger, dan Line Messenger.

Berdasarkan analisis aplikasi terhadap aplikasi sejenis, mobile chat application yang dirancang memiliki kelebihan yang dimiliki yakni dapat menangani data yang besar dan memiliki pengaksesan data dan performa yang lebih baik serta memiliki beberapa fitur tambahan seperti sharefile pada group, block broadcast message, pengaturan status keaktifan user, penerjemahan bahasa dari bahasa inggris ke bahasa Indonesia dan sebaliknya serta pemberian Feedback. 
Tabel 2 Tabel Analisis Aplikasi Terhadap Aplikasi Sejenis

\begin{tabular}{|c|c|c|c|c|c|}
\hline & Fitur & $\begin{array}{l}\text { Blackberry } \\
\text { Messenger }\end{array}$ & $\begin{array}{l}\text { WhatsApp } \\
\text { Messenger }\end{array}$ & $\begin{array}{l}\text { Line } \\
\text { Messenger }\end{array}$ & $\begin{array}{c}\text { Using } \\
\text { MongoDB }\end{array}$ \\
\hline \multirow{4}{*}{ Private Chat } & Pengiriman Gambar & $\sqrt{ }$ & $\sqrt{ }$ & $\sqrt{ }$ & $\sqrt{ }$ \\
\hline & Pengiriman Suara & $\sqrt{ }$ & $\sqrt{ }$ & $\sqrt{ }$ & $\sqrt{ }$ \\
\hline & Pengiriman Video & $\times$ & $\sqrt{ }$ & $\sqrt{ }$ & $\sqrt{ }$ \\
\hline & Pengiriman File & $\sqrt{ }$ & $x$ & $x$ & $\sqrt{ }$ \\
\hline \multirow{4}{*}{ Conference Chat } & Pengiriman Gambar & $\sqrt{ }$ & $x$ & $\sqrt{ }$ & $\sqrt{ }$ \\
\hline & Pengiriman Suara & $\sqrt{ }$ & $x$ & $\sqrt{ }$ & $\sqrt{ }$ \\
\hline & Pengiriman Video & $x$ & $x$ & $\sqrt{ }$ & $\sqrt{ }$ \\
\hline & Pengiriman File & $\sqrt{ }$ & $x$ & $x$ & $\sqrt{ }$ \\
\hline \multirow{4}{*}{ Group } & Sharing Gambar & $\sqrt{ }$ & $\sqrt{ }$ & $\sqrt{ }$ & $\sqrt{ }$ \\
\hline & Sharing Suara & $x$ & $\sqrt{ }$ & $\sqrt{ }$ & $\sqrt{ }$ \\
\hline & SharingVideo & $x$ & $\sqrt{ }$ & $\sqrt{ }$ & $\sqrt{ }$ \\
\hline & SharingFile & $x$ & $\times$ & $x$ & $\sqrt{ }$ \\
\hline \multirow{3}{*}{$\begin{array}{l}\text { Pengaturan } \\
\text { Pesan }\end{array}$} & Block Broadcast Message & $x$ & $x$ & $x$ & $\sqrt{ }$ \\
\hline & Pengaturan Suara & $\sqrt{ }$ & $\sqrt{ }$ & $\sqrt{ }$ & $\sqrt{ }$ \\
\hline & Pengaturan Getaran & $\sqrt{ }$ & $\sqrt{ }$ & $\sqrt{ }$ & $\sqrt{ }$ \\
\hline \multirow{2}{*}{$\begin{array}{l}\text { Pengaturan } \\
\text { Teman }\end{array}$} & Block Friends & $\sqrt{ }$ & $\sqrt{ }$ & $\sqrt{ }$ & $\sqrt{ }$ \\
\hline & Pengaturan Status Keaktifan User & $x$ & $x$ & $x$ & $\sqrt{ }$ \\
\hline \multirow{6}{*}{ Lainnya } & Penerjemahan Bahasa & $x$ & $\times$ & $\times$ & $\sqrt{ }$ \\
\hline & Pemberian Feedback & $x$ & $\times$ & $\times$ & $\sqrt{ }$ \\
\hline & Free Call & $x$ & $x$ & $\sqrt{ }$ & $\sqrt{ }$ \\
\hline & $\begin{array}{l}\text { Pemberian Respons pada Aktivitas } \\
\text { User }\end{array}$ & $\times$ & $\times$ & $\sqrt{ }$ & $\sqrt{ }$ \\
\hline & Mengetahui Lokasi Teman & $\sqrt{ }$ & $\sqrt{ }$ & $\sqrt{ }$ & $\sqrt{ }$ \\
\hline & Emoticon & $\sqrt{ }$ & $\sqrt{ }$ & $\sqrt{ }$ & $\sqrt{ }$ \\
\hline
\end{tabular}

\section{Evaluasi Berdasarkan Kuesioner}

Hasil yang diperoleh berdasarkan hasil kuesioner kepada beberapa responden yang mencoba demo mobile chat application adalah dapat disimpulkan bahwa responden sudah merasa puas untuk fitur baru, kecepatan, dan user interfaceyang dimiliki. Selain itu juga, dari hasil kuesioner ini, didapatkan komentar \&saran untuk pengembangan selanjutnya.

\section{Evaluasi Berdasarkan Hasil Wawancara}

Evaluasi dilakukan dengan cara melakukan wawancara terhadap pakar Information Technology (IT). Hasil yang didapat adalah jika dilihat dari segi kecepatannya, aplikasi ini sudah memiliki performa yang cukup baik, respon dan pengirimannya cepat, tidak terlalu berat dan belum ditemukan masalah seperti terlalu berat dalam mengirim data. Untuk kedepannya dapat dioptimalisasi lagi untuk memperhatikan faktor eksternal seperti koneksi internet dari masing masing user. 


\section{Evaluasi Terhadap Lima Faktor Manusia Terukur}

Aplikasi memenuhi lima faktor manusia terukur, yang meliputi waktu untuk belajar, kecepatan kinerja, tingkat kesalahan user, daya ingat, dan kepuasan subjektif

\section{Evaluasi Terhadap Sepuluh Prinsip Perancangan Mobile Application}

Aplikasi sudah memenuhi sepuluh prinsip perancangan mobile application, yang meliputi: Mobile Mindset, Mobile Contexts, Global Guidelines, Navigation Models, User Input, Gestures, Orientation, Communications, Launching dan First Impressions

\section{SIMPULAN}

Berdasarkan analisis terhadap hasil evaluasi, maka hal-hal yang dapat disimpulkan dari penelitianini adalah: (1) NoSQL Technology seperti MongoDB dapat digunakan pada mobile chat application berbasis Android dengan kecepatan akses yang lebih cepat. (2) Mobile chat application ini dikembangkan sesuai dengan delapan aturan emas, memenuhi lima faktor manusia terukur, dan prinsip perancangan mobile application berdasarkan Stark (2012).

Berdasarkan simpulan yang diperoleh, maka ada beberapa saran yang dipertimbangkan untuk pengembangan aplikasi selanjutnya yaitu: penggunaan NoSQL Technology seperti MongoDB pada sistem operasi selain Android seperti sistem operasi Blackberry dan IOS (IPhone Operating System), serta digunaakan untuk pengaksesan data secara real-time.

\section{DAFTAR PUSTAKA}

Darcey, L., Conder, S. (2012). Learning Android ${ }^{\mathrm{TM}}$ Application Programming for the Kindle Fire ${ }^{\mathrm{TM}}$. USA: Addison-Wesley.

Gargenta, M. (2011). Learning Android. USA: O’Reilly Media, Inc.

Idrees, M. (2012). MongoDB. Software Developer's New Ideas \& Solutions for Professional Programmers, 3-4.

Jayathiloha, D., Fernando, A., Sooriyaarachchi, C. (2012). Thinking Big to Deal with Big Data - A Practical Insight into MongoDB. Software Developer's New Ideas \& Solutions for Professional Programmers, 44.

Meier, R. (2010). Professional Android ${ }^{\mathrm{TM}} 2$ Application Development. Indianapolis: Wiley Publishing, Inc.

Seguin, K. (2012). The Little MongoDB Book. San Francisco: GitHub Inc.

Stark,J. (2012). 10 Principles Mobile Interface Design. Diakses 1 November 2012, dari http://www.creativebloq.com/mobile/10-principles-mobile-interface-design-4122910.

Tiwari, S. (2011). Professional NoSQL. Indianapolis: John Wiley \& Sons, Inc. 